\title{
VIBRATIONAL SPECTRA OF HEXAAQUACOMPLEXES. XII. ON THE POSSIBLE ANION DISORDER IN SELENATE ALUMS: PREDICTION OF THE CRYSTAL STRUCTURE AND VIBRATIONAL SPECTRA OF KAl(SeO $\left.)_{4}\right)_{2} \cdot \mathbf{1 2 H}_{2} \mathrm{O}$ AND RELATED ALUMS*
}

\author{
Vladimir M. Petruševski \\ Institute of Chemistry, Faculty of Natural Sciences and Mathematics, Ss. Cyril and Methodius University, \\ Arhimedova 5, PO Box 162, 1001 Skopje, Republic of Macedonia \\ vladop@pmf.ukim.mk
}

\begin{abstract}
A survey is given for the crystallographic and vibrational spectroscopic results of a number of alums. From both types of results (structural and spectroscopic) it is positively known that the sulfate $\alpha$ alums exhibit orientational disorder of the sulfate anions along the threefold symmetry axis. Both IR and Raman spectra confirm the finding for sulfate disorder in $\mathrm{KAl}\left(\mathrm{SO}_{4}\right)_{2} \cdot 12 \mathrm{H}_{2} \mathrm{O}$. Only the Raman spectra show clearly that the sulfate anions in many $\mathrm{K}, \mathrm{Tl}$ and $\mathrm{Rb}$ are indeed disordered, in excellent agreement with the crystallographic results [1]. The disorder depends on the nature and size of $\mathrm{M}^{\mathrm{I}}$ cations in the structure, the smaller the radius, the larger the disorder. Thus no anion disorder has been detected so far in selenate alums. The structure prediction of $\mathrm{KAl}\left(\mathrm{SeO}_{4}\right)_{2} \cdot 12 \mathrm{H}_{2} \mathrm{O}$ allows the existence of disorder of the selenate groups. The latter seems to be corroborated by the study of the Raman spectra of selenate $\alpha$ alums. It is thus worthwhile to have the crystal structure of $\mathrm{KAl}\left(\mathrm{SeO}_{4}\right)_{2} \cdot 12 \mathrm{H}_{2} \mathrm{O}$ refined, in order to check this prediction and as an additional check of the general explanation for the sulfate anion disorder in alums, offered earlier [1].
\end{abstract}

Keywords: alums; crystal structure; prediction of; vibrational spectra; sulfates; selenates; anion disorder

\section{ВИБРАЦИОНИ СПЕКТРИ НА ХЕКСААКВА-КОМПЛЕКСИ. ХІІ. ЗА МОЖНАТА НЕСРЕДЕНОСТ НА АНЈОНИТЕ КАЈ СЕЛЕНАТНИТЕ СТИПСИ: ПРЕДВИДУВАҢЕ НА КРИСТАЛНАТА СТРУКТУРА И ВИБРАЦИОНИ СПЕКТРИ HA KAl( $\left.\mathrm{SeO}_{4}\right)_{2} \cdot \mathbf{1 2 H}_{2} \mathrm{O}$ И СРОДНИ СТИПСИ}

\begin{abstract}
Даден е преглед на кристалографските и спектроскопските резултати на голем број стипси. Од двата типа резултати (структурни и спектроскопски) со сигурност се знае дека сулфатните $\alpha$ стипси покажуваат постоење на ориентациона несреденост на анјоните долж оската на симетрија од трет ред. И инфрацрвените и раманските спектри го потврдуваат наодот за несреденост на сулфатните анјони кај $\mathrm{KAl}\left(\mathrm{SO}_{4}\right)_{2} \cdot 12 \mathrm{H}_{2} \mathrm{O}$. Единствено во раманските спектри јасно се гледа постоење на анјонска несреденост во многу стипси на $\mathrm{K}$, $\mathrm{Tl}$ и $\mathrm{Rb}$, во целосна согласност со кристалографските податоци [1]. Несреденоста зависи од природата и големината на $\mathrm{M}^{\mathrm{I}}$ - катјоните во структурата: колку што е помал радиусот толку поголем е степенот на несреденоста. Кај селенатните стипси не е детектирана анјонска несреденост. Предвидувањето на структурата на $\mathrm{KAl}\left(\mathrm{SeO}_{4}\right)_{2} \cdot 12 \mathrm{H}_{2} \mathrm{O}$ дозволува постоење на несреденост на селенатните групи. Последниов наод изгледа дека е во согласност и со испитаните рамански спектри на селенатни $\alpha$-стипси. Според тоа, изгледа важно да се реши структурата на $\mathrm{KAl}\left(\mathrm{SeO}_{4}\right)_{2} \cdot 12 \mathrm{H}_{2} \mathrm{O}$, и за да се провери валидноста на предвидувањето, но и како дополнителен тест за порано понуденото објаснение за постоење на анјонска несреденост кај стипсите [1].
\end{abstract}

Клучни зборови: стипси; кристална структура; предвидување; вибрациони спектри; сулфати; селенати; несреденост на анјоните

\footnotetext{
- Dedicated to Academician Gligor Jovanovski on the occasion of his $70^{\text {th }}$ birthday.
} 


\section{PROLOGUE}

I was delighted and honored by the offer of the Editorial Board to submit a manuscript on this occasion. Thinking about a suitable topic, I recalled that my very first steps in the structural chemistry investigations (those date back for almost four decades) were to grow single crystals of several alums with an idea (suggested by my professor and mentor Bojan Šoptrajanov) to study their Raman spectra. In the course of the preparation of the compounds and growing suitable single crystals, I was directly supervised by my teaching assistant Gligor Jovanovski, today an eminent crystallographer. Some of the results of that study were soon published [2]. Since then, the structures and vibrational spectra of alums became my passion and object of my continuous interest; hence the choice of the subject emerged naturally. I am glad that a former 'candidate' of mine, now professor, Vladimir Ivanovski showed interest in this manuscript and gladly agreed to be my informal reviewer. I thank him for the suggestions in the course of writing of this manuscript...

\section{INTRODUCTION}

Alums are compounds with a general formula $\mathrm{M}^{\mathrm{I}} \mathrm{M}^{\mathrm{III}}\left(\mathrm{XO}_{4}\right)_{2} \cdot 12 \mathrm{H}_{2} \mathrm{O}$. $\mathrm{M}^{\mathrm{I}}$ is a univalent metal ( $\mathrm{Na}, \mathrm{K}, \mathrm{Rb}, \mathrm{Cs}, \mathrm{Tl}), \mathrm{M}^{\mathrm{III}}$ is a trivalent one (Al, Ga, In, Ti, V, Cr, Mo, Fe, Ru, Co, Rh, Ir), and $\mathrm{X}$ is $\mathrm{S}$ or Se. As for $\mathrm{M}^{\mathrm{I}}$, it can also be $\mathrm{NH}_{4}, \mathrm{CH}_{3} \mathrm{NH}_{3}$, $\mathrm{NH}_{3} \mathrm{OH}, \mathrm{N}_{2} \mathrm{H}_{5}$, etc. Further, at least one alum exists with $\mathrm{Sc}$, i.e. $\mathrm{CsSc}\left(\mathrm{SO}_{4}\right)_{2} \cdot 12 \mathrm{H}_{2} \mathrm{O}$ [3]. The latter publication deserves the attention of crystallographers. Tetrafluoroberylate alums are also known $[4,5]$, meaning that the tetraoxoanion $\mathrm{XO}_{4}{ }^{2-}$ might be substituted with $\mathrm{BeF}_{4}{ }^{2-}$. It is generally believed that $\mathrm{Li}$ is too small to enter a structure of alum, although eight decades ago Spencer and Oddie [6] claimed to have synthesized a double sulfate salt of aluminum and lithium, containing the right proportion of water expected for a dodecahydrate and, even more important, the crystals were found to be isotropic! In the light of the mentioned findings it seems really unjust that this publication was obviously foreseen by all forthcoming researchers (it has never been cited in the extensive literature on alums, for example). Thus, the statement (a possible fallacy) that lithium does not form alums persists for almost eight decades!

In order to simplify things in a straightforward way, we will adopt the following abbreviation system: any alum will be designated by three symbols, which are often (albeit not always) the chemical symbols for $\mathrm{M}^{\mathrm{I}}, \mathrm{M}^{\mathrm{III}}$ and $\mathrm{X}$, followed by D (an acronym for dodecahydrate): thus KAlSD stands for potassium aluminum sulfate dodecahydrate, $\mathrm{AFeSeD}$ is ammonium iron selenate dodecahydrate, $\mathrm{MCrBeD}$ is methylammonium chromium tetrafluoroberyllate dodecahydrate etc.

\subsection{Survey of crystallographic results}

Alums were, at first, thought to be all isomorphous until Lipson [7-9] discovered that there are actually three alum types, designated (in the order of their discovery) as $\alpha, \beta$ and $\gamma$ alums. According to Lipson, $\alpha$ alums form with $\mathrm{M}^{\mathrm{I}}$ cations of intermediate size; thus, $\mathrm{K}, \mathrm{Tl}, \mathrm{NH}_{4}, \mathrm{Rb}$ all form $\alpha$ alums. If the $\mathrm{M}^{\mathrm{I}}$ cation is large (like the one of Cs or $\mathrm{CH}_{3} \mathrm{NH}_{3}$ ), a $\beta$ alum is formed. Finally, with small $\mathrm{M}^{\mathrm{I}}$ cations $(\mathrm{Na}), \gamma$ alums are formed [9]. The non-isomorphism of the alums was immediately noticed, as the unit cell edge of NaAlSD (12.19 $\AA)$ was significantly bigger compared to that in KAlSD (12.13 $\AA$ ). Lipson found that the orientation of the sulfate groups along the 'triade' axis in NaAlSD is opposite (inverted) with respect to KAlSD or CsAlSD. Interestingly, Lipson attempted to offer some arguments for the non-existence of lithium alums (this was, however, a year prior to the discovery of Spencer and Oddie [6]).

Studies on refinements of the structure and of various mixed alums crystals were performed in the early 40 's of the $20^{\text {th }}$ century (see. [10] and the references therein), although no improvement was done on the understanding of the structural subtleties of the members of this family. A very important publication came 2 decades later, by Haussühl [11], where he offered unequivocal classification of more than 60 different alums, assigning each of them to a certain type: $\alpha, \beta$ or $\gamma$. This had been done purely on the basis of the morphology of the alum crystals, and the value of it is that for more than 5 decades it has never appeared to be wrong! The careful measurement of the lattice constants shows without any doubt that Lipson was right in finding that, contrary to expectations based on ion sizes, the cell edge of NaAlSD is indeed bigger than that of KAISD.

In the 50's and especially in the 60's and 70 's, an important step forward has been made. Bacon and Gardner [12] for the first time get insight into the geometry of the hydrogen bonds in $\mathrm{KCrSD}$ and the positions of the four crystallographically different $\mathrm{H}$-atoms in the structure. Fletcher and Steeple [13] confirm Lipson's notion about dimorphism in methylammonium alum and refine the structure of the low-temperature phase [14]. 
The next 5 decades bring a number of publications on structure determinations and refinements of many alums [15-41]. Perhaps the first Xray and neutron diffraction data with more or less acceptable reliability appear in the 60's and are published by Cromer, Kay and Larson ('the Los Alamos group' [15-18, 23]). They confirmed the initial Lipson's results, that in $\gamma$ alums [16] the orientation of sulfate tetrahedra is inverted along the threefold axis, while $\alpha$ and $\beta$ alums differ in the coordination number of the $\mathrm{M}^{\mathrm{I}}$ cations (six in $\alpha$ and twelve in $\beta$ alums). These authors were the first to detect sulfate group disorder in KAlSD, and to a lesser extent in AAISD [17, 18].

Roughly in the same time, Ledsham and Steeple worked on the structure types of various chromium alums [19-22]. They concluded that practically all chromium alums are of the same type as their aluminum counterparts, with the exception of $\mathrm{NaCrSD}$ (this one was found to be of $\alpha$ and not of $\gamma$ type). If this conclusion was true, then it would be necessary to explain the counterintuitive trend of the unit-cell parameters, as $a(\mathrm{NaCrSD})>a(\mathrm{KCrSD})$, since both alums are allegedly of the same type $[1,20]$, but the radii of the hexacoordinated $\mathrm{M}^{\mathrm{I}}$ cations are markedly different, with $R\left(\mathrm{Na}^{+}\right)<R\left(\mathrm{~K}^{+}\right)$. The former problem was the one that intrigued Rees-Isele and Keller to redetermine the structure of NaCrSD. They found that the double sulfate of sodium and chromium is a hexahydrate rather than an alum [42]. In fact, according to these authors, a sodium chromium alum does not exist at all [43]. We will briefly turn our attention to this assertion later.

Few years later, Sugusch [24] reported the structural results for CsTiSD. As expected (on the basis of Haussühl results [11]) the alum was found to be of $\beta$ type.

A still deeper understanding of the alum structures comes from the series of studies performed by Beattie et al. ('the Australian group', $[25,28,30])$. Later more researchers joined this group and valuable papers were published [31-39]. The most important discovery of the Australian group is a precise and straightforward criterion for distinguishing $\alpha$ and $\beta$ alums, on the basis of some geometrical/structural arguments. They found [25] that the crucial difference between the two types is the $\mathrm{O}_{\mathrm{w}}-\mathrm{M}^{\mathrm{I}}-\mathrm{O}_{\mathrm{w}}$ angle. This angle is almost exactly $60^{\circ}$ in $\beta$ alums (in the range of $60-60.2^{\circ}$ ), while in $\alpha$ alums it is significantly larger (in the range 64.6$66.5^{\circ}$ ). The latter criterion leads to a straightforward classification that is also in a complete agreement with the results of Haussühl [11]. The new criterion was important, as the CsCoSD,
CsRhSD and CsIrSD alums were all found to be of $\alpha$ type $[25,28]$ despite the presence of large $M^{I}$ (Cs) that would lead, according to Lipson [9], to a $\beta$ type structure. They also confirmed (once again!) that Haussühl [11] was right to assign all selenate alums but MAlSeD to the $\alpha$ type $[30,32,38]$.

The small number of other studies $[26,27$, 29] deals with three $\alpha$ alums: HaAlSD [26], MAlSD [27] (due to dimorphism it has a $\beta$ modification as well) and a newly refined structure of AAlSD [27], as well as with a $\beta$ alum CsMoSD [29]. The latter was the first time that an alum containing molybdenum was studied. All studied $\alpha$ alums exhibit a sulfate disorder. This is in line with other structural studies $[1,17,18]$. We shall deal with this topic in detail later.

\subsection{Survey of spectroscopic results}

The spectroscopic results are numerous and cover a period of almost 5 decades [44-79]. Among the first papers is that of Harmelin and Duval [44]. Their conclusion, that the $\mathrm{KCrSD}$ alums is actually $\left[\mathrm{KCr}\left(\mathrm{SO}_{6} \mathrm{H}_{4}\right)_{2}\left(\mathrm{H}_{2} \mathrm{O}\right)_{2}\right] \cdot 6 \mathrm{H}_{2} \mathrm{O}$ is in sharp disagreement with the crystallographic results of Lipson [9]. The latter were evidently available to the authors, so it is difficult to explain what led them to the obviously wrong conclusion.

The first Raman spectra of KAlSD (together with the spectra of other hexa-aqua complexes) were studied by Ananthanarayanan [45]. Using a mercury lamp as an excitation source, he offered assignment of some of the Raman bands to the skeletal motions of the $\mathrm{AlO}_{6}$ octahedron. This assignment appears to be wrong, as shown by subsequent studies where laser sources were used (Ananthanarayanan's frequencies were, simply, chosen to be too low).

Prask and Boutin [46] analyzed the spectra of inelastic neutron scattering and assign few of the bands (or inflection points) on the profile to motions that involve the water molecules. The quality of the instrumentation (in that period, almost 5 decades ago) is such that the results are next to useless!

Petrov et al. [47] used a clever method (study of various alums with different $\mathrm{M}^{\mathrm{I}}$ and $\mathrm{M}^{\mathrm{III}}$ cations) to successfully assign the bands associated with the $\mathrm{M}^{\mathrm{III}}-\mathrm{W}_{6}$ skeletal motions, as these are sensitive to the nature/mass of the $\mathrm{M}^{\mathrm{III}}$ cations. Studying also samples with various (sulfate or selenate anions) it appeared possible to easily assign the bands due to the anion. The assignments of some of the other bands in the spectra are, however, questionable. 
Campbell et al. [48] correctly assigned most of the water librational bands, as far as one is interested which bands are related to librations of $\mathrm{W}^{\mathrm{III}}$ or to $\mathrm{W}^{\mathrm{I}}$ (water molecules coordinated to univalent and trivalent metal cation, respectively). However, the assignment to rock and wag motions is done based on the belief that the rocking librations appear at higher frequencies, something that is not always justified (as evidenced by later model calculations [80]).

Venkatesh \& Narayanan [49] were the first to confirm the notion (suggested by crystallographers) for sulphate disorder in the $\alpha$ alum KAlSD, using IR spectroscopy. Later, other authors gave additional evidence for a disorder in both KAlSD $[53,54,56,58,63]$ as well as in other $\alpha$ alums [1, 77]. This will be discussed in more details later.

Three more papers appeared in this period [50-52] with only marginal impact. Only the paper of Strupler \& Guillermet [52] should perhaps be mentioned, as they presented (for the first time) the IR spectrum of a vanadium alum, CsVSD. Also, an assignment is offered for the unexpected band at $\sim 2450 \mathrm{~cm}^{-1}$, as a result of second-order transition.

The first far IR spectral results (supported with the single-crystal Raman spectra of the lowfrequency region) were discussed by Eckert, Eysel and Kampffmeyer [55]. The authors offered sound reasons for the assignment of the lattice modes (hindered rotations and hindered translations) of the sulfate/selenate sublattice, as well as skeletal modes of the $\mathrm{M}^{\mathrm{I}} \mathrm{W}_{6}$ and $\mathrm{M}^{\mathrm{III}} \mathrm{W}_{6}$ groups.

Precious conclusions were gained from the spectroscopic results of the Australian group [57, $59,61,62,67,69,71-74]$. In reference 57, they confirmed the assignment of the fundamental skeletal modes of the $\mathrm{M}^{\mathrm{III}} \mathrm{W}_{6}$ groups, first offered by Petrov et al. [47]. However, Best et al. [57] studied the spectra on a superior IR instrument (Perkin Elmer 580) and employed both low-temperature IR spectroscopy, as well as isotopic substitution $\left({ }^{51} \mathrm{Cr} /{ }^{53} \mathrm{Cr}\right)$ for positive identification of these bands, something that is much less ambiguous than the (always questionable) normal-coordinate treatment, that Petrov et al. [47] performed in addition to their low-quality spectra. Some assignments of the water librations are clearly wrong, as shown by later studies (Petruševski \& Šoptrajanov [65]).

In the later works this group of authors [59, $61,62,67,69$ ] paid attention to the Raman spectra of many cesium alums, but also to some rubidium ones [71]. In all studies, the region between 300 and $1200 \mathrm{~cm}^{-1}$ is explored. This is the region in which bands due to the internal vibrations of the tetrahedral anions, water librations and $\mathrm{M}^{\mathrm{III}} \mathrm{W}_{6}$ skeletal modes appear. Best et al. [59, 61] made very reasonable band assignments for all modes in this region but the water librations. The latter assignments are basically in line with their first published spectroscopic results [57]. There is a slight progress in their next paper [62], where they simply labeled the water librational bands, without insisting on more precise assignment.

The work of Petruševski \& Šoptrajanov [65] deals with the room and low-temperature (RT and LNT) spectra of CsAlSD. In fact a series of partly deuterated compounds was prepared, that enabled the authors to conclude that it is possible to assign the water librations to librations of rocking, wagging and twisting type, in good agreement with the predictions of Eriksson and Lindgren [80], based on model calculations. These results were then criticized by Best et al. [67], who found (in their Raman spectra of a partly deuterated CsAISD analogue) ".... a clearly defined ... shoulder ... which cannot be attributed either to isotopically pure librations or the arithmetic mean of a single libration". Whatever the meaning of the latter statement was, the authors seemed to rely heavily on their Raman spectra, although they must have been aware of the fact that water librations give only weak Raman bands (and water librations of the isotopomers in partly deuterated samples are even weaker). Armstrong et al. [69] insisted on basically the same assignment in the Raman spectra of CsMoSD and CsRuSD single crystals, and these include also the questional assignments of the librational bands of the water molecules. The same happens in a later paper of Tregenna-Piggott \& Best [71], as well as in Berry et al. [74], while subsequent papers $[72,73]$ are devoted to the study of the Jahn-Teller interactions in samples of CsTiSD and RbTiSD.

Few of the papers devoted to vibrational spectroscopic results are of, more or less, marginal importance. The one of Bernard \& Ludy [64] deals, for the first time, with a ruthenium alum (CsRuSD) and with normal-coordinate treatment of the $\mathrm{Ru}\left(\mathrm{H}_{2} \mathrm{O}\right)_{6}{ }^{3+}$ and $\mathrm{Ru}\left(\mathrm{H}_{2} \mathrm{O}\right)_{6}{ }^{2+}$ ions. Torgashev et al. [64] presented the Raman spectra of MAlSD, while Suresh et al. [70] gave low-quality Raman spectra of single crystals of RAISD (spectra of much better quality were discussed by TregennaPiggott and Best [71]).

Malekfar and Sherman [66] discussed for the first time the reflection spectra of KAlSD, and from there calculated the frequencies of the TO and LO modes. Some of their assignments are, however, unfeasible. Šoptrajanov \& Petruševski discussed, for the first time, the $\mathrm{HOH}$ bending re- 
gion in several alums. At LNT a whole progression of bands is evident in $\alpha$ alums, while a complex feature is seen in those of $\beta$ type. Ivanovski et al. $[75,76]$ studied the reflection spectra of several alums, to conclude that the LO-TO splitting dominates over both site-group and correlation-field splitting. Spectroscopic criteria for distinguishing alums of $\alpha$ from those of $\beta$ type were thoroughly discussed by Petruševski \& Šoptrajanov [2002]. Interestingly, while discussing spectra of various sulfate minerals in Macedonia, Makreski et al. [79] identified the potassium alum by its infrared spectrum (given its high solubility in water, such a mineral is not really expected to exist as a natural one).

We now turn to the central issue of this paper, namely to

\subsection{The sulfate disorder in the a alums}

The disorder of the sulfate anions in $\alpha$ alums was first discovered (as already mentioned) in the crystallographic studies done by the Los-Alamos group [17, 18]. The disordered sulfate groups adopt the configuration originally found in the only known member of the $\gamma$ alums subset [16] (i.e. the trigonal oxygen atoms point toward the $\mathrm{M}^{\mathrm{I}}$ cations). Larson and Cromer [17] mentioned that 'the fraction of reversed sulfate groups apparently increases as the monovalent cation decreases in size. More crystallographic studies followed later, the results of which show that the extent of disorder is some $3 \%$ in HaAlSD [26], about $4.2 \%$ MAlSD and $\approx 17 \%$ in AAlSD [27]. All structural studies indicate that the disordered sulfate groups are in the same time more distorted than the regular ones.

It was mentioned earlier that Venkatesh \& Narayanan [49], studying the IR spectrum of KAISD, were able to detect bands that could be consistently explained in terms of disordered $\mathrm{SO}_{4}{ }^{2-}$ anions in the structure. The spectral picture is also consistent with the finding [17] that the disordered anions are in the same time more distorted, but the authors missed the opportunity to confirm it by independent (i.e. IR) method. Later, they claimed [53] that a disorder exists also in NaAlSD! However, they did not mention on what basis they made that conclusion. The paper is, namely, too short (it is a conference paper) and it is not clear whether they recorded their spectra in mulls or pellets. If $\mathrm{KBr}$ pellets were used, the inevitable double exchange of $\mathrm{Na}$ with $\mathrm{K}$ from the matrix would definitely be at the origin of the (erroneous) conclusion. Other authors studied the Raman spectra of several $\alpha$ alums, to conclude that the extent of disorder indeed depends on the size of the univalent cation [54], and that it is temperature sensitive. Eysel and Schumacher [56] allowed for either disorder [17] or large thermal amplitudes of the atoms. As there was no broadening of the Raman lines, they concluded that this temperature sensitive behavior is due to sulfate disorder. They postulated an unsymmetrical double minimum potential for rotation of the sulfate group around an axis perpendicular to the $C_{3}$ axis of the crystal. That, also, explains the different intensity of the two $v_{1}\left(\mathrm{SO}_{4}\right)$ bands as a result of unequal population of the two sites.

Sood et al. [58] performed precise measurements of band intensities as a function of temperature. Down to $150 \mathrm{~K}$ it seems feasible to assume only classical Boltzman distribution factors as governing the temperature dependent disorder (i.e. an Arrhenius behavior is detected). However, below that temperature there is a marked deviation of the actual band intensities ratio from the expected one. The authors introduced another, temperature independent mechanism that is responsible for the departures from the distribution of MaxwellBoltzman type.

Brooker and Eysel [63] obtained excellent new results by studying pure KAlSD samples (both protiated and deuterated) at different temperatures, but also samples enriched by ${ }^{18} \mathrm{O}$ isotopomers (that is, in some $8 \%$ of the sulfate anions, ${ }^{16} \mathrm{O}$ was replaced by ${ }^{18} \mathrm{O}$ ). The measurements of the relative intensities for the bands associated with the two sites for the isotopically dilute $\mathrm{S}^{18} \mathrm{O}_{4}{ }^{2-}$ ions showed that the second site was essentially unoccupied at low temperatures thus showing Arrhenius behavior in the entire temperature range. It was then concluded that, in the authors' own words '... intermolecular modes of vibration between different $\mathrm{SO}_{4}{ }^{2-}$ ions in the ordered lattice of the pure alums imparted an unexpected stability to the second site and this coupling strength became greater at lower temperature. The isotopically dilute $\mathrm{S}^{18} \mathrm{O}_{4}{ }^{2-}$ ions were totally decoupled from the ordered lattice and did not have the added stabilization from the resonance energy-exchange process...'.

All of the previous findings were confirmed by a much more reliable structural refinement of 5 different $\alpha$ alums [1] that was supported by Raman spectroscopic measurements, as well as with a more detailed subsequent study [77]. In the X-ray study, it was noticed for the first time that there exists an odd behavior in the geometry of the disordered sulfate ions and their immediate environment. This odd behavior is pictured in Table 1. For reasons of consistency, in all cases, both actual and 
'simulated' sulfate disorders are given (the latter is important, for there is no disorder in CsAlSD). The disorder was simulated by placing the oxygen atoms at positions that are mirror images of the original ones, the mirror plane passing through the sulfur atom and being perpendicular to the $C_{3}$ axis. The results are the following:

Table 1

$M^{I}-W_{1}$ and $M^{I}-O I^{\prime}$ distances

(the prime refers to the trigonal oxygen atoms

within the disordered sulfate anions, actual or simulated, as explained in the text above)

\begin{tabular}{ccccc}
\hline \hline \multirow{2}{*}{ Alum/Distance } & $\mathrm{M}^{\mathrm{I}}-\mathrm{W}_{1} /$ & \multicolumn{2}{c}{$\mathrm{M}^{\mathrm{I}}-\mathrm{O}^{\prime} / \mathrm{pm}$} & Reference \\
& $\mathrm{pm}$ & simulated & actual & \\
\hline KAlSD & 295.4 & 260.6 & 263.5 & 1 \\
KCrSD & 301.0 & 258.0 & 265 & 1 \\
TlAlSD & 307.7 & 255.6 & 259 & 1 \\
TlGaSD & 308.1 & 252.7 & 260 & 1 \\
RbGaSD & 308.1 & 253.5 & 254 & 1 \\
CsAlSD & 335.3 & 219.3 & - & 25 \\
\hline \hline
\end{tabular}

Firstly, let us conclude that the difference between the actual distances and those calculated for the simulated disordered anions is small enough. Therefore, the simulated disordered atoms may be easily used instead of the actual ones, whenever estimations of interatomic distances are needed. Secondly, when comparing the $\mathrm{M}^{\mathrm{I}}-\mathrm{W}_{1}$ distances with the $\mathrm{M}^{\mathrm{I}}-\mathrm{O}^{\prime}(\mathrm{S})$, the odd-behavior becomes obvious: the larger the radius of $\mathrm{M}^{\mathrm{I}}$ [81], the longer the $\mathrm{M}^{\mathrm{I}}-\mathrm{W}_{1}$ distance, as it should be. However, the trend in the $\mathrm{M}^{\mathrm{I}}-\mathrm{O}^{\prime}(\mathrm{S})$ contacts is opposite, which is indeed unusual! As a consequence, $\operatorname{larger} \mathrm{M}^{\mathrm{I}}$ cations will more efficiently flip the disordered sulfate oxygen atoms back to their 'original' positions (i.e. the oxygens from the minor site will be pushed back to the positions characteristic for the major site [1]). Thirdly, it now becomes clear, why no disorder has ever been detected in any $\beta$ alum. Namely, as a rule, $\beta$ alums are formed with large univalent cations in which case the hypothetical $\mathrm{M}^{\mathrm{I}}-\mathrm{O}^{\prime}(\mathrm{S})$ contacts become unfeasibly short.

All known cases, so far, of alums with disordered anions are sulfate alums. A question crops immediately: is it possible to have a selenate alum with $\mathrm{SeO}_{4}$ disorder? None of the selenate alums with known crystal structure (all of which belong to the $\alpha$ type) show signs of $\mathrm{SeO}_{4}$ disorder. However, all these are cesium alums! From what was said before, it would be reasonable to assume that only selenate alums with relatively small $\mathrm{M}^{\mathrm{I}}$ cations could be candidates for selenate disorder. In order to possibly answer the previous question, we now turn to the

\subsection{Prediction of the crystal structure of KAlSeD: Are the selenate anions disordered?}

The crystal structure of KAlSeD has never been refined in detail. However, in few of our previous publications, we successfully predicted the complete crystal structures of several compounds [82-84], that are members of various isomorphous series. A justification for the method used was also offered [85]. In short, for members of isomorphous series one should expect systematic variation of both the cell parameters and the fractional coordinates, with the effective crystal radii of the atoms/ions that are the building blocks. In our case, a set of least squares equations of the form

$$
D=\beta_{0}+\beta_{1} \cdot R_{1} / \AA+\beta_{3} \cdot R_{3} / \AA+\beta_{\mathrm{XO}} \cdot R_{\mathrm{XO}} / \AA
$$

may be used, where $D$ is the dependent variable to be predicted (fractional coordinate or cell edge parameter); $R_{1}$ and $R_{3}$ are the effective crystal radii [81] of $\mathrm{M}^{\mathrm{I}}$ and $\mathrm{M}^{\mathrm{III}}$ cations; $R_{\mathrm{XO}}$ is the $\mathrm{S}-\mathrm{O}$, i.e. Se$\mathrm{O}$ distance (again calculated as a sum of the corresponding Shannon radii) and $\beta_{i}$-s are the least square coefficients obtained by multiple linear regression (MLR).

One should first build a database of precisely refined structures of alums belonging to the $\alpha$ type. Such a database could be built from precisely refined structures only, in order to ensure more reliable predictions. Further, a restricted subset $\left(\mathrm{M}^{\mathrm{III}}=\mathrm{Al}, \mathrm{Ga}, \mathrm{In} ; \mathrm{M}^{\mathrm{I}}=\mathrm{K}, \mathrm{Tl}, \mathrm{Rb}, \mathrm{Cs}\right)$ of structures was used in which, obviousy, no transition metals appear (previous experience showed us that even simple predictions of the cell edges require using more independent variables whenever transition metal compounds are included [86, 87]). All of the mentioned univalent and trivalent cations have completely filled shells/subshells, and therefore the ground term for each of them is ${ }^{1} \mathrm{~S}_{0}$. The input data (taken from references 1 and 30) are summarized in Tables 2 and 3. 
T a ble 2

The actual values for the dependent variables used in the MLR (values for $K, T l$ and $\mathrm{Rb}$ alums taken from [1] and those for Cs alums from [30]); $\mathrm{O1}$ and $\mathrm{O} 2$ are the 'trigonal and general sulfate oxygen atoms, while W1 and W3 the oxygen atoms of water molecules coordinated to $K$ and Al, respectively; $a$ is the cell-edge parameter; $K$ and $A l$ are fixed by symmetry and were placed at $0.5,0.5,0.5$ and at $0,0,0$, respectively

\begin{tabular}{crrrrrr}
\hline \hline Var/alum & KAlSD & TlA1SD & TlGaSD & RbGaSD & CsAlSeD & CsInSeD \\
\hline$x$ (S) & 0.3076 & 0.3114 & 0.3130 & 0.3130 & 0.3140 & 0.3157 \\
$x$ (O1) & 0.2390 & 0.2434 & 0.2454 & 0.2453 & 0.2393 & 0.2413 \\
$x$ (O2) & 0.3097 & 0.3157 & 0.3178 & 0.3178 & 0.3208 & 0.3204 \\
$y(\mathrm{O} 2)$ & 0.2648 & 0.2676 & 0.2700 & 0.2701 & 0.2643 & 0.2695 \\
$z(\mathrm{O} 2)$ & 0.4208 & 0.4232 & 0.4249 & 0.4245 & 0.4336 & 0.4353 \\
$x$ (W1) & 0.0463 & 0.0461 & 0.0486 & 0.0479 & 0.0451 & 0.0496 \\
$y(\mathrm{~W} 1)$ & 0.1336 & 0.1399 & 0.1433 & 0.1425 & 0.1395 & 0.1462 \\
$z$ (W1) & 0.3026 & 0.2973 & 0.2987 & 0.2988 & 0.2888 & 0.2977 \\
$x(\mathrm{~W} 3)$ & 0.1518 & 0.1521 & 0.1579 & 0.1577 & 0.1487 & 0.1677 \\
$y$ (W3) & 0.0198 & 0.0151 & 0.0104 & 0.0107 & 0.0117 & 0.0055 \\
$z$ (W3) & 0.9814 & 0.9856 & 0.9876 & 0.9875 & 0.9877 & 0.9901 \\
$a / \AA$ & 12.1640 & 12.2305 & 12.2368 & 12.2679 & 12.5440 & 12.6940 \\
\hline \hline
\end{tabular}

\section{T a b le 3}

Values for the independent variables used in the MLR (all values taken from [81]

\begin{tabular}{llll}
\hline \hline Alum & $R_{1} / \AA$ & $R_{3} / \AA$ & $R_{\mathrm{XO}} / \AA$ \\
\hline KAlSD & 1.38 & 0.535 & 1.47 \\
TlAlSD & 1.50 & 0.535 & 1.47 \\
TlGaSD & 1.50 & 0.620 & 1.47 \\
RbGaSD & 1.52 & 0.620 & 1.47 \\
CsAlSeD & 1.67 & 0.535 & 1.63 \\
CsInSeD & 1.67 & 0.800 & 1.63 \\
\hline \hline
\end{tabular}

The above input in the MLR (standard software package, i.e. IBM SPSS Version 22.0 was used) results in the following output:

T a ble 4

Least-squares values (upper) and standard deviations (lower rows) for the $\beta_{i}$ coefficients, obtained by MLR. Rightmost column gives the values for regression coefficients

\begin{tabular}{|c|c|c|c|c|c|c|c|c|c|c|c|}
\hline Variable & $\beta_{0}$ & $\beta_{1}$ & $\beta_{3}$ & $\beta_{\mathrm{XO}}$ & 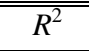 & Variable & $\beta_{0}$ & $\beta_{1}$ & $\beta_{3}$ & $\beta_{\mathrm{XO}}$ & $R^{2}$ \\
\hline \multirow[t]{2}{*}{$x(\mathrm{~S})$} & 0.291 & 0.034 & 0.008 & -0.024 & 0.986 & $y(\mathrm{~W} 1)$ & 0.135 & 0.053 & 0.026 & -0.060 & 0.981 \\
\hline & 0.005 & 0.005 & 0.003 & 0.006 & & & 0.008 & 0.009 & 0.005 & 0.012 & \\
\hline \multirow{2}{*}{$x(\mathrm{O} 1)$} & 0.286 & 0.041 & 0.009 & -0.076 & 0.978 & $z$ (W1) & 0.349 & -0.046 & 0.032 & - & 0.990 \\
\hline & 0.006 & 0.006 & 0.003 & 0.008 & & & 0.004 & 0.003 & 0.003 & & \\
\hline \multirow[t]{2}{*}{$x(\mathrm{O} 2)$} & 0.285 & 0.058 & - & -0.037 & 0.972 & $x$ (W3) & 0.142 & - & 0.071 & -0.019 & 0.999 \\
\hline & 0.008 & 0.008 & & 0.011 & & & 0.002 & & 0.001 & 0.001 & \\
\hline \multirow[t]{2}{*}{$y(\mathrm{O} 2)$} & 0.293 & 0.026 & 0.020 & -0.051 & 0.993 & $y(\mathrm{~W} 3)$ & 0.041 & -0.049 & -0.026 & 0.041 & 0.972 \\
\hline & 0.003 & 0.003 & 0.002 & 0.004 & & & 0.011 & 0.012 & 0.006 & 0.016 & \\
\hline \multirow[t]{2}{*}{$z(\mathrm{O} 2)$} & 0.331 & 0.023 & 0.007 & 0.037 & 0.996 & $z$ (W3) & 0.969 & 0.038 & 0.010 & -0.031 & 0.983 \\
\hline & 0.005 & 0.005 & 0.003 & 0.007 & & & 0.005 & 0.006 & 0.003 & 0.007 & \\
\hline \multirow[t]{2}{*}{$x$ (W1) } & 0.051 & - & 0.018 & -0.019 & 0.960 & $a / \AA ̊$ & 8.863 & 0.411 & 0.522 & 1.680 & 0.996 \\
\hline & 0.004 & & 0.002 & 0.003 & & & 0.175 & 0.187 & 0.101 & 0.245 & \\
\hline
\end{tabular}

When the above values for the $\beta$-coefficients and the values for the radii (cf. Table 3 ) are substituted in equation 1 (a total of 11 equations for predicting the 10 fractional coordinates plus the cell- edge parameter, $a$, are obtained in this way) it is possible to predict the complete structure of KAlSeD (except for the hydrogen atom positions, due to lack of reliable neutron diffraction data): 
Table 5

Predicted values for the structure parameters in KAlSeD

\begin{tabular}{cr}
\hline \hline Variable & KAlSeD \\
\hline$x(\mathrm{Se})$ & 0.3031 \\
$x(\mathrm{O} 1)$ & 0.2235 \\
$x(\mathrm{O} 2)$ & 0.3047 \\
$y(\mathrm{O} 2)$ & 0.2564 \\
$z(\mathrm{O} 2)$ & 0.4268 \\
$x(\mathrm{~W} 1)$ & 0.0297 \\
$y(\mathrm{~W} 1)$ & 0.1242 \\
$z(\mathrm{~W} 1)$ & 0.3026 \\
$x(\mathrm{~W} 3)$ & 0.1490 \\
$y(\mathrm{~W} 3)$ & 0.0263 \\
$z(\mathrm{~W} 3)$ & 0.9763 \\
$a / \AA$ & 12.4478 \\
\hline \hline
\end{tabular}

It should be mentioned that various groups of authors use different notations for the atoms in the structure. Also, some authors put $\mathrm{M}^{\mathrm{I}}$ at $0.5,0.5$, 0.5 and $\mathrm{M}^{\mathrm{III}}$ at $0,0,0$, while others prefer the opposite $\left(\mathrm{M}^{\mathrm{III}}\right.$ at $0.5,0.5,0.5$ and $\mathrm{M}^{\mathrm{I}}$ at $\left.0,0,0\right)$. Simple transformations of coordinates were needed occasionally, for the input data set (cf. Table 2) to be consistent.

Next, a calculation of interatomic distances was performed using the program DISTAN [88]. Two distances are of interest in this context: $\mathrm{K}-\mathrm{W}_{1}$ $=292.6 \mathrm{pm}$, and $\mathrm{K}-\mathrm{O} 1^{\prime}=252.9 \mathrm{pm}$. Comparing these distances with those in $\mathrm{KAlSD}\left(\mathrm{K}-\mathrm{W}_{1}=\right.$ $295.4 \mathrm{pm}$, and $\left.\mathrm{K}-\mathrm{O} 1^{\prime}=260.6 \mathrm{pm},[1]\right)$ it seems reasonable to assume that the $\mathrm{K}-\mathrm{O} 1$ ' contacts are indeed shorter in KAlSeD. If the true cause for the sulfate disorder is indeed the one hypothesized by Nyburg et al. [1], then the only logical consequence is that one could expect selenate disorder in KAlSeD, albeit to a lesser extent than in KAlSD. This had to be checked spectroscopically.

\section{EXPERIMENTAL}

In order to obtain large single crystals of a good quality, sulfate alums were synthesized by slow evaporation from aqueous solutions of stoichiometric amounts of the corresponding salts. A parallel attempt to synthesize alums from chloride or nitrate salts in diluted sulfuric acid appeared to be completely successful and was used in the synthesis of some selenate alums (one recrystallization in the latter case appeared to be sufficient for obtaining single crystals free of the spectator ions).

FT IR spectra were recorded using a specular reflection accessory, on a Perkin Elmer System 2000 instrument. Typically, depending on the sample size, 16 or 32 scans were used for the background spectrum and 32, 64 or 128 spectra for the sample spectrum. The resolution $\left(4 \mathrm{~cm}^{-1}\right)$ and the OPD velocity of the mirror $(0.2 \mathrm{~cm} / \mathrm{s})$ were the same in all cases. The Kramers-Kronig transformation [89] was employed to calculate the absorption spectra from the reflection ones. The spectra obtained in this way were almost identical to the transmission spectra obtained from pressed $\mathrm{KBr}$ disks or mulls in Nujol between $\mathrm{KBr}$ plates.

The Raman spectra were recorded on a Jobin Yvon T64000 Raman system. The excitation source was INNOVA 300 FRED $\mathrm{Ar}^{+}$laser operating at either 514.3 or $488 \mathrm{~nm}$. For colorless systems the power was adjusted to $\approx 1 \mathrm{~W}$. The resolution was about $3 \mathrm{~cm}^{-1}$ and the wave-number accuracy was about $1 \mathrm{~cm}^{-1}$.

Grams Analyst [90] and Grams/32 [91] software packages were used for spectra acquisition and manipulation, respectively.

\section{RESULTS AND DISCUSSION}

The spectra of a number of different alums were recorded and analyzed. Some of the results regarding the sulfate disorder were reported earlier $[1,77]$. Because of that, we keep the number of figures at the bare minimum.

The IR spectra (originally reflection spectra that were transformed to absorbance), are presented below. NaAlSD (cf. Figure 1) is the only known member of the $\gamma$ class. No disorder was indicated for this alum in the course of the structural study [16]. The bands in the spectrum (at $\approx 920$ and 1110 $\mathrm{cm}^{-1}$ ) could be reasonably assigned to a $\mathrm{HOH}$ libration (wagging mode of the water molecules coordinated to $\mathrm{Al}[65])$ and to $v_{3}\left(\mathrm{SO}_{4}\right)$, respectively. Alternative assignments for the water librational band exist in the literature and were mentioned in the above survey of the spectroscopic results.

Unlike NaAlSD, KAISD [1] shows very pronounced $\mathrm{SO}_{4}$ disorder, as was already discussed earlier. The comparison of the NaAlSD spectrum with that of potassium alum (cf. Figure 2) shows the existence of three extra bands (at $\approx 975,1070$ and $1095 \mathrm{~cm}^{-1}$ ) in the IR spectrum of the latter. The band at $\approx 975 \mathrm{~cm}^{-1}$ could be assigned to the $v_{1}$, while the bands at $\approx 1070$ and $1095 \mathrm{~cm}^{-1}$ are due to site-group components of the $v_{3}$ modes of the disordered sulfate groups. The large splitting $(\approx 125$ $\mathrm{cm}^{-1}$ ) can easily be explained by the fact that the disordered (minor) ions are highly distorted compared to the regular (major) ones [1].

That the sulfate anions are indeed disordered can even better be demonstrated (from a spectroscopic viewpoint) by the study of the Raman spectra. Thus, in the region of the symmetric stretching 
vibrations of the sulfate anions (cf. Fig. 3) there are 2 bands, at $\approx 975$ and $990 \mathrm{~cm}^{-1}$. The one at lower frequency originates from the symmetric stretching mode of the minor (disordered) sulfates, while the other is due to the major ones. From the ratio of the integrated intensities of the two bands, one can easily calculate the site occupancies as 0.308 and 0.692 for the minor and major sites, respectively, in ideal agreement with the X-ray results (i.e. with 0.303 and 0.697).

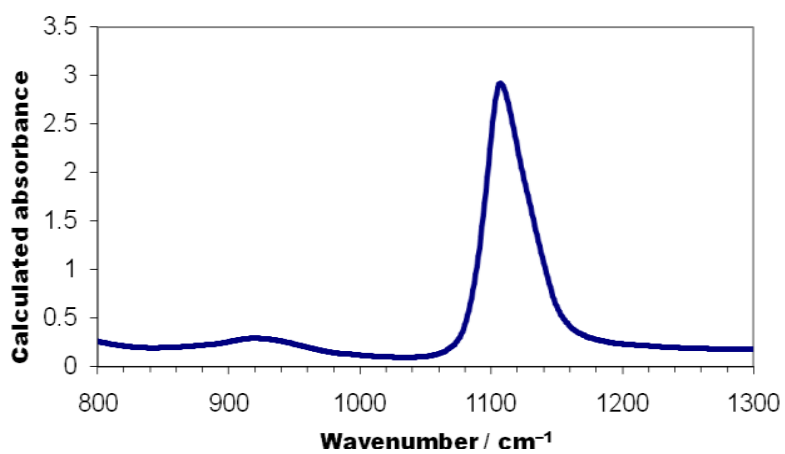

Fig. 1: IR spectrum of NaAlSD in the region of the $\mathrm{SO}_{4}$ stretching vibrations

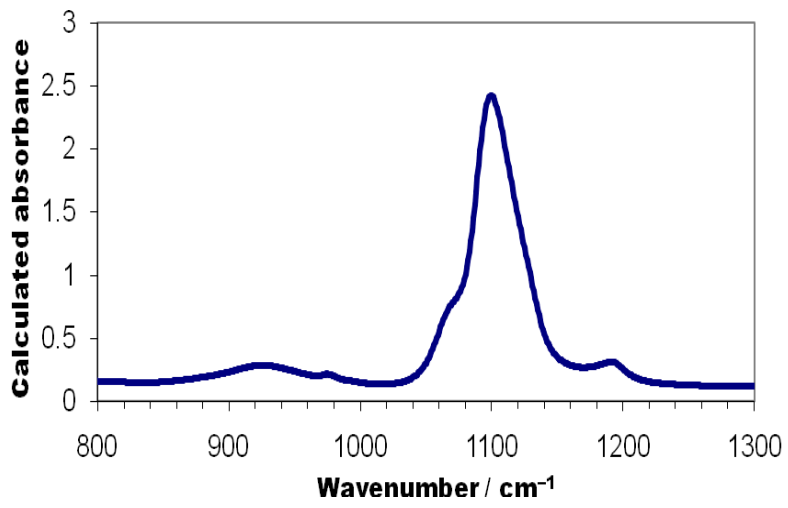

Fig. 2: IR spectrum of KAlSD in the region of the $\mathrm{SO}_{4}$ stretching vibrations

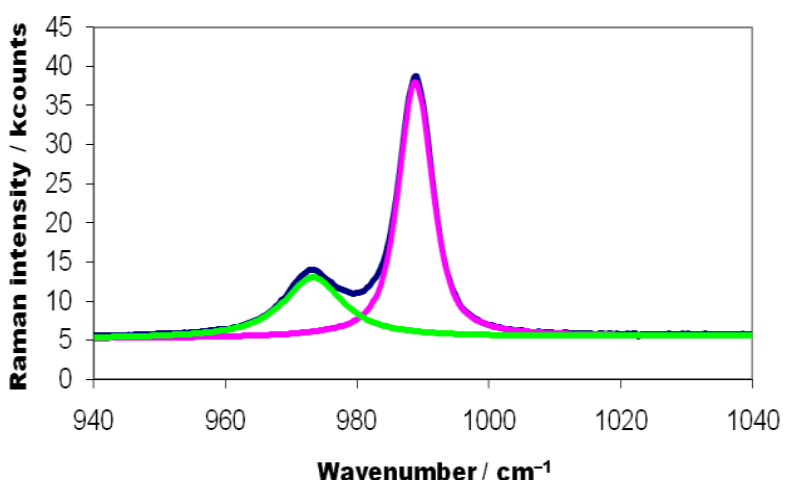

Fig. 3. Raman spectrum of KAlSD in the region of the $v_{1}\left(\mathrm{SO}_{4}\right)$ mode: blue - actual spectrum; purple - $v_{1}\left(\mathrm{SO}_{4}\right)$, major site; green $-v_{1}\left(\mathrm{SO}_{4}\right)^{\prime}$, minor site

(both components obtained by curve fitting).
In order to solve the crucial question ("Is there any selenate disorder in KAlSeD?"), we now turn to the Raman spectra of $\mathrm{CsGaSeD}$ and KAlSeD (both are $\alpha$ alums, as we mentioned earlier). The structure refinement of both CsAlSeD and $\mathrm{CsInSeD}$ [30] revealed no $\mathrm{SeO}_{4}$ disorder. This could actually be a priori predicted, on the basis of the explanations offered in [1], namely that it is quite unlikely to have much shorter $\mathrm{M}^{\mathrm{I}}-\mathrm{W}_{1}$ contacts than expected on the basis of the sum of Shannon's radii [81]. In such a case, there are strong repulsive forces that prevent such kind of orientational disorder. Consequently, the Raman spectrum of $\mathrm{CsGaSeD}$ (the three bands present in the region of the selenate stretchings) can be easily explaind as a result of the symmetric $\mathrm{SeO}_{4}$ stretch $\left(\approx 840 \mathrm{~cm}^{-1}\right)$, the antisymmetric stretch $\left(\approx 890 \mathrm{~cm}^{-1}\right)$ and a weak band due to water libration (possibly the twisting $\mathrm{W}_{3}$ mode) at $\approx 850 \mathrm{~cm}^{-1}$ (cf. Figure 4 ).

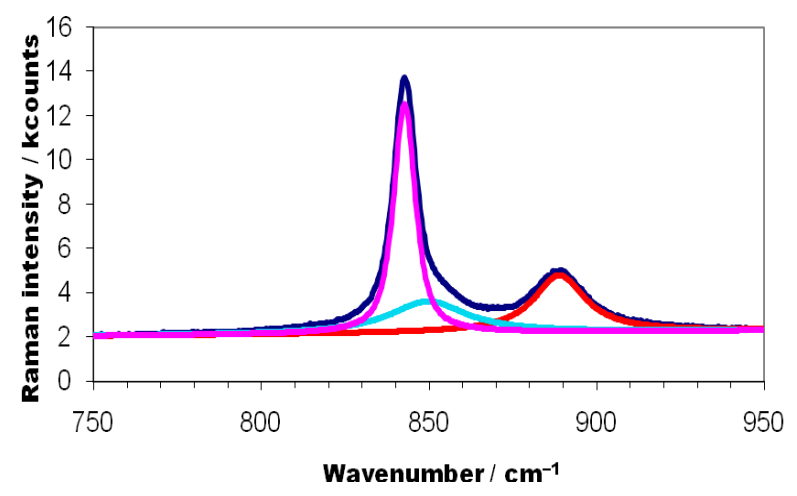

Fig. 4. Raman spectrum of $\mathrm{CsGaSeD}$ in the region of the selenate stretching modes: blue - actual spectrum; purple $v_{1}\left(\mathrm{SeO}_{4}\right)$; red $-v_{3}\left(\mathrm{SeO}_{4}\right)$; cyan $-\mathrm{H}_{2} \mathrm{O}$ libration (all components obtained by curve fitting).

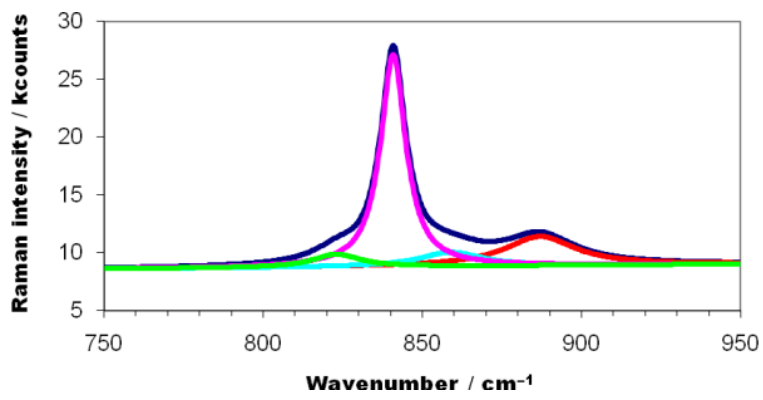

Fig. 5. Raman spectrum of KAlSeD in the region of the selenate stretching modes: blue - actual spectrum; purple $-v_{1}\left(\mathrm{SeO}_{4}\right)$, major site; green $-v_{1}\left(\mathrm{SeO}_{4}\right)^{\prime}$, minor site; red $-v_{3}\left(\mathrm{SeO}_{4}\right)$; cyan $-\mathrm{H}_{2} \mathrm{O}$ libration (all components obtained by curve fitting).

The spectral picture of KAlSeD in this region is slightly different (cf. Figure 5). The three bands mentioned above are present at almost exactly the same frequencies $\left(\approx 840 \mathrm{~cm}^{-1}\right.$ and $\approx 890$ 
$\mathrm{cm}^{-1}$ for the symmetric and antisymmetric stretching vibrations of the $\mathrm{SeO}_{4}$ groups), while the band due to the water libration appears at $\approx 860 \mathrm{~cm}^{-1}$. The latter fact is one more argument for the correctness of the assignment of this band. Namely, the effective crystal radii (cf. Table 3) decrease in the sequence $\mathrm{In}^{3+}>\mathrm{Ga}^{3+}>\mathrm{Al}^{3+}$. In the same sequence, the bond-strength $\mathrm{M}^{\mathrm{III}}-\mathrm{W}_{3}$ increases. The latter affects the librational $\mathrm{HOH}$ frequencies: the higher the bond-order, the higher the frequency. This is the probable reason for the higher frequency of the librational band in KAlSeD compared to that in CsGaSeD (cf. Table 6). However, the important detail is the extra peak in $\mathrm{KAlSeD}$ at $823.0 \mathrm{~cm}^{-1}$.
There is no other logical explanation, but to assign it to the minor $\left(\mathrm{SeO}_{4}{ }^{\prime}\right)$ anions. The normalized area immediately gives the occupation $(10 \%)$ of the minor site. It is significantly lower than that in the analogous sulfate. Once again, it is perfectly logical why is this value lower than the sulfate one $(30.8 \%)$. The selenate anion is more bulky than the sulfate one. Upon 'inverting' it, it comes closer to $\mathrm{K}$, than it is in $\mathrm{KAlSD}$, and the $\mathrm{SeO}_{4}$ is more efficiently 'flipped back' to the major position. Actually, the degree of disorder (the site occupancy) corresponds to that found in rubidium alums, just as the $\mathrm{K}-\mathrm{W}_{1}$ contacts are in very good agreement with $\mathrm{Rb}-\mathrm{W}_{1}$ [1].

Table 6

Vibrational modes and some of their spectral parameters in three studied $\alpha$ alums: primes (') refer to minor sulfate/selenate sites; FWHMI = full width at half-maximum intensiry; the total area under the peaks due to the $v_{l}\left(\mathrm{XO}_{4}\right)$ and $v_{1}\left(\mathrm{XO}_{4}\right)^{\prime}$ modes is normalized to 1

\begin{tabular}{|c|c|c|c|}
\hline Modes \& parameters & KAlSD & KAlSeD & CsGaSeD \\
\hline \multicolumn{4}{|l|}{$v_{1}\left(\mathrm{XO}_{4}\right)$} \\
\hline Band centre $/ \mathrm{cm}^{-1}$ & 988.8 & 840.8 & 842.7 \\
\hline FWHMI $/ \mathrm{cm}^{-1}$ & 6.1 & 9.5 & 7.7 \\
\hline Normalized area & 0.692 & 0.900 & 1.000 \\
\hline \multicolumn{4}{|l|}{$v_{1}\left(\mathrm{XO}_{4}\right)^{\prime}$} \\
\hline Band centre $/ \mathrm{cm}^{-1}$ & 973.3 & 823.0 & \\
\hline $\mathrm{FWHMI} / \mathrm{cm}^{-1}$ & 10.9 & 17.7 & \\
\hline Normalized area & 0.308 & 0.100 & \\
\hline \multicolumn{4}{|l|}{$\tau(\mathrm{HOH})$} \\
\hline Band centre $/ \mathrm{cm}^{-1}$ & & 858.9 & 849.7 \\
\hline FWHMI $/ \mathrm{cm}^{-1}$ & & 23.7 & 27.9 \\
\hline \multicolumn{4}{|l|}{$v_{3}\left(\mathrm{SeO}_{4}\right)$} \\
\hline Band centre $/ \mathrm{cm}^{-1}$ & & 886.9 & 888.9 \\
\hline $\mathrm{FWHMI} / \mathrm{cm}^{-1}$ & & 26.8 & 18.6 \\
\hline
\end{tabular}

Therefore, it would be really interesting to check these predictions by solving the crystal structure of KAlSeD and we challenge our crystallographic colleagues to do it and prove or disprove the assumptions and conclusions offered here.

\section{REFERENCES}

[1] S. C. Nyburg, J. W. Steed, S. Aleksovska, V. M. Petruševski, Structure of the alums. I. On the sulfate group disorder in the $\alpha$-alums, Acta Crystallogr., B56, 204-209 (2000).

[2] В. Петрушевски, Б. Шоптрајанов, Г. Јовановски, Спектарот на водата кај некои сулфатни и селенатни стипси, 7. Југословенско саветовање „Општа и примењена спектроскопија“. Зборник радова, 1978, Ниш, 105-111.

[3] B. I. Bashkov, L. N. Komissarova, F. M. Spiridonov, V. M. Shatsky, Vestn. Mosk. Univ. Khim., 5, 598-600 (1972).
[4] A. Lari-Lavassani, C. Avinens, L. Cot, Préparation et étude radiocristallographique des aluns fluorobéryllates de chrome, C. R. Acad. Sci. Paris, C268, 1782-1784 (1969).

[5] A. Lari-Lavassani, C. Avinens, L. Cot, Sur l'existence et la cristallographie de quelques nouveaux fluorobéryllates doubles de chrome $\left[\mathrm{CH}_{3} \mathrm{NH}_{3}\right] \mathrm{Cr}\left(\mathrm{BeF}_{4}\right)_{2} \cdot 12 \mathrm{H}_{2} \mathrm{O}$, $\left[\mathrm{C}\left(\mathrm{NH}_{2}\right)_{3}\right] \mathrm{Cr}\left(\mathrm{BeF}_{4}\right)_{2} \cdot 12 \mathrm{H}_{2} \mathrm{O}$ et $\left[\mathrm{C}\left(\mathrm{NH}_{2}\right)_{3}\right] \mathrm{Cr}\left(\mathrm{BeF}_{4}\right)_{2} \cdot 6 \mathrm{H}_{2} \mathrm{O}$, C. R. Acad. Sci. Paris, C270, 1973-1975 (1970).

[6] J. F. Spencer, G. T. Oddie, Preparation of lithium alum, Nature, 138, 169 (1936).

[7] H. Lipson, C. A. Beevers, The crystal structure of the alums, Proc. Roy. Soc., A148, 664-680 (1934).

[8] H. Lipson, Existence of three alum structures, Nature, 134, 327 (1935).

[9] H. Lipson, The relation between the alum structures, Proc. Roy. Soc., A151, 347-356 (1935).

[10] H. P. Klug, L. Alexander, Crystal-chemical studies of alums. III. Further solid solution studies, J. Am. Chem. Soc., 62, 2993-2995 (1940). 
[11] S. Haussühl, Kristallographie der alaune, I, Z. Kristallogr., 116, 371-405 (1961).

[12] G. E. Bacon, W. E. Gardner, The structure of chromium potassium alum, Proc. Roy. Soc. Section, A246, 78-90 (1958).

[13] R. O. W. Fletcher, H. Steeple, Dimorphism in methyl ammonium alum, Acta Crystallogr., 15, 960-963 (1962).

[14] R. O. W. Fletcher, H. Steeple, The crystal structure of the low-temperature phase of methylammonium alum, Acta Crystallogr., 17, 290-294 (1964).

[15] D. T. Cromer, M. I. Kay, A. C. Larson, Refinement of the alum structures. I. X-ray and neutron diffraction study of $\mathrm{CsAl}\left(\mathrm{SO}_{4}\right)_{2} \cdot 12 \mathrm{H}_{2} \mathrm{O}$, a $\beta$ alum, Acta Crystallogr., 21, 383-389 (1966).

[16] D. T. Cromer, M. I. Kay, A. C. Larson, Refinement of the alum structures. II. X-ray and neutron diffraction study of $\mathrm{NaAl}\left(\mathrm{SO}_{4}\right)_{2} \cdot 12 \mathrm{H}_{2} \mathrm{O}, \gamma$ alum, Acta Crystallogr., 22, 182-187 (1967).

[17] A. C. Larson, D. T. Cromer, Refinement of the alum structures. III. X-ray study of the $\alpha$ alums, $\mathrm{K}, \mathrm{Rb}$ and $\mathrm{NH}_{4} \mathrm{Al}\left(\mathrm{SO}_{4}\right)_{2} \cdot 12 \mathrm{H}_{2} \mathrm{O}$, Acta Crystallogr., 22, 793-800 (1967).

[18] D. T. Cromer, M. I. Kay, Refinement of the alum structures. IV. Neutron diffraction study of deuterated ammonium alum, $\mathrm{ND}_{4} \mathrm{Al}\left(\mathrm{SO}_{4}\right)_{2} \cdot 12 \mathrm{D}_{2} \mathrm{O}$, an $\alpha$ alum, Acta Crystallogr., 22, 800-805 (1967).

[19] A. H. C. Ledsham, H. Steeple, The crystal structure of methylammonium chromium alum, Acta Crystallogr., B24, 320-322 (1968).

[20] A. H. C. Ledsham, H. Steeple, The crystal structures of sodium chromium alum and caesium chromium alum, Acta Crystallogr., B24, 1287-1289 (1968).

[21] A. H. C. Ledsham, H. Steeple, The classification of chromium alums, Acta Crystallogr., B25, 398-400 (1969).

[22] A. H. C. Ledsham, H. Steeple, W. Hughes, The behaviour of the sulphate group in the alum structures, Acta Crystallogr., B26, 1240-1244 (1970).

[23] M. I. Kay, D. T. Cromer, Thermal motion of the sulfate group in sodium alum $\mathrm{NaAl}\left(\mathrm{SO}_{4}\right)_{2} \cdot 12 \mathrm{H}_{2} \mathrm{O}$, Acta Crystallogr., B26, 1349-1355 (1970).

[24] J. Sygusch, Refinement of $\beta$-alum $\mathrm{CsTi}\left(\mathrm{SO}_{4}\right)_{2} \cdot 12 \mathrm{H}_{2} \mathrm{O}$, Acta Crystallogr., B30, 662-665 (1974).

[25] J. K. Beattie, S. P. Best, B. W. Skelton, A. H. White, Structural studies on the caesium alums, $\mathrm{CsM}^{\mathrm{III}}\left[\mathrm{SO}_{4}\right]_{2} \cdot 12 \mathrm{H}_{2} \mathrm{O}$, J. Chem. Soc. Dalton Trans., 2105-2111 (1981).

[26] A. M. Abdeen, G. Will, A. Weiss, Neutron diffraction study of alums, Z. Kristallogr., 154, 45-57 (1981).

[27] A. M. Abdeen, G. Will, W. Schäfer, A. Kirfel, M. O. Bargouth, K. Recker, X-ray and neutron diffraction study of alums, Z. Kristallogr., 157, 147-166 (1981).

[28] R. S. Armstrong, J. K. Beattie, S. P. Best, Crystal structures of the $\alpha$ alums $\mathrm{CsM}\left[\mathrm{SO}_{4}\right]_{2} \cdot 12 \mathrm{H}_{2} \mathrm{O}(\mathrm{M}=\mathrm{Rh}$ or Ir), J. Chem. Soc. Dalton Trans., 1973-1975 (1983).

[29] M. Brorson, M. Gajhede, Crystal structure of cesium molybdenium alum, $\mathrm{Cs}\left[\mathrm{Mo}\left(\mathrm{H}_{2} \mathrm{O}\right)_{6}\right]\left(\mathrm{SO}_{4}\right)_{2} \cdot 6 \mathrm{H}_{2} \mathrm{O}$ at 110 $\mathrm{K}$, Inorg. Chem., 26, 2109-2112 (1987).
[30] R. S. Armstrong, J. K. Beattie, S. P. Best, G. P. Braithwaite, P. Del Favero, B. W. Skelton, Crystal structures of the selenate alums $\mathrm{CsM}\left[\mathrm{SeO}_{4}\right]_{2} \cdot 12 \mathrm{H}_{2} \mathrm{O}(\mathrm{M}=\mathrm{Al}$, Cr, Fe, Rh or In), Aust. J. Chem., 43, 393-398 (1990).

[31] S. P. Best, J. B. Forsyth, Low-temperature neutrondiffraction structure of $\left[\mathrm{Ru}\left(\mathrm{OH}_{2}\right)_{6}\right]^{3+}$ in the caesium sulphate alum lattice $\mathrm{CsRu}\left(\mathrm{SO}_{4}\right)_{2} \cdot 12 \mathrm{H}_{2} \mathrm{O}$, J. Chem. Soc. Dalton Trans., 3507-3511 (1990).

[32] S. P. Best, J. B. Forsyth, Stereochemistry of tervalent aqua ions: low-temperature neutron diffraction structures of $\mathrm{CsFe}\left(\mathrm{SO}_{4}\right)_{2} \cdot 12 \mathrm{H}_{2} \mathrm{O}$ and $\mathrm{CsFe}\left(\mathrm{SeO}_{4}\right)_{2} \cdot 12 \mathrm{H}_{2} \mathrm{O}, J$. Chem. Soc. Dalton Trans., 395-400 (1990).

[33] S. P. Best, J. B. Forsyth, Relationship between the electronic and molecular structure of tervalent aqua ions: low-temperature neutron diffraction structure of $\mathrm{CsCr}\left(\mathrm{SO}_{4}\right)_{2} \cdot 12 \mathrm{H}_{2} \mathrm{O}$, J. Chem. Soc. Dalton Trans., 17211725 (1991).

[34] S. P. Best, J. B. Forsyth, P. L. Tregenna-Piggott, Influence of the stereochemistry of water co-ordination to metal(III) cations on the $\mathrm{M}-\mathrm{O}$ bond length and electronic structure of the cation, J. Chem. Soc. Dalton Trans., 2711-2715 (1993).

[35] J. K. Beattie, S. P. Best, F. H. Moore, P. Del Favero, B. W. Skelton, A. H. White, Water molecule dispositions in the caesium sulfate $\alpha$ and $\beta$ alums: single-crystal neutron diffraction studies of $\mathrm{CsM}\left[\mathrm{SO}_{4}\right]_{2} \cdot 12 \mathrm{H}_{2} \mathrm{O}(\mathrm{M}=\mathrm{V}, \mathrm{Rh})$, Aust. J. Chem., 46, 1337-1345 (1993).

[36] S. P. Best, B. N. Figgis, J. B. Forsyth, P. A. Reynolds, P. L. W. Tregenna-Piggott, Spin distribution and bonding in $\left[\mathrm{Mo}\left(\mathrm{OD}_{2}\right)_{6}\right]^{3+}$, Inorg. Chem., 34, 4605-4610 (1995).

[37] J. K. Beattie, S. P. Best, P. Del Favero, B. W. Skelton, A. N. Sobolev, A. H. White, Alkali-metal vanadium sulfate $\beta$ alums, $\mathrm{MV}\left[\mathrm{SO}_{4}\right]_{2} \cdot 12 \mathrm{H}_{2} \mathrm{O}(\mathrm{M}=\mathrm{K}, \mathrm{Rb}$ or $\mathrm{Cs})$ : structural anomalies related to unsymmetrical occupancy of the $\mathrm{t}_{2 \mathrm{~g}}\left(O_{h}\right)$ orbitals, J. Chem. Soc. Dalton Trans., 1481-1486 (1996).

[38] B. N. Figgis, P. A. Reynolds, A. N. Sobolev, The structure of the $\alpha$ alums $\mathrm{RbCr}\left(\mathrm{SO}_{4}\right)_{2} \cdot 12 \mathrm{H}_{2} \mathrm{O}$ and $\mathrm{CsCr}\left(\mathrm{SeO}_{4}\right)_{2} \cdot 12 \mathrm{H}_{2} \mathrm{O}$, Acta Crystallogr., C56, 731-734 (2000).

[39] P. L. W. Tregenna-Piggott, D. Spichiger, G. Carver, B. Frey, R. Meier, H. Weihe, J. A. Cowan, G. J. McIntyre, G. Zahn, A.-L. Barra, Structure and bonding of the vanadium(III) hexa-aqua cation. 1. Experimental characterization and ligand-field analysis, Inorg. Chem., 43, 8049-8060 (2004).

[40] M. V. Barashkov, A. I. Komyak, S. N. Shashkov, Vibrational spectra and structure of potassium alum $\mathrm{KAl}\left(\mathrm{SO}_{4}\right)_{2} \cdot 12\left(\mathrm{H}_{2} \mathrm{O}\right)_{x}\left(\mathrm{D}_{2} \mathrm{O}\right)_{1-x}$, J. Appl. Spectr., 71, 328333 (2004).

[41] N. Rempfer, H.-W. Lerner, M. Bolte, The ammonium chromium(III) alum $\mathrm{NH}_{4} \mathrm{Cr}\left(\mathrm{SO}_{4}\right)_{2} \cdot 12 \mathrm{H}_{2} \mathrm{O}$, Acta Crystal$\log r$., E60, i80-i81 (2004).

[42] L. Rees-Isele, E. Keller, In search of the true structure of the sodium chromium alum: crystal growth and structure of the double salt $\mathrm{NaCr}\left(\mathrm{SO}_{4}\right)_{2}\left(\mathrm{H}_{2} \mathrm{O}\right)_{6}, Z$. Naturforsch., 67b, 1229-1234 (2012).

[43] L. Rees-Isele, H.-P. Winkler, E. Keller, In search of the true structure of the sodium chromium alum. II. Crystal growth and structure of the double salt $\mathrm{NaCr}\left(\mathrm{SO}_{4}\right)_{2}\left(\mathrm{H}_{2} \mathrm{O}\right)_{6} \cdot\left(\mathrm{CH}_{3} \mathrm{OH}\right)_{0.6(2)} \cdot\left(\mathrm{H}_{2} \mathrm{O}\right)_{1.5(5)}$, Z. Naturforsch., 68b, 1288-1294 (2013). 
[44] M. Harmelin, C. Duval, Étude physico-chimique de la structure de l'alun de chrome, Mikrochim. Acta., 5-6, 863-882 (1960).

[45] V. Ananthanarayanan, Vibrational spectra of the octahedral water complexes in hydrated sulphates, Z. Phys. Chem. (Leipzig), 222, 102-110 (1963).

[46] H. J. Prask, H. Boutin, Low-frequency motions of $\mathrm{H}_{2} \mathrm{O}$ molecules in crystals. III, J. Chem. Phys., 45, 32843295 (1966).

[47] К. Н. Петров, Н. К. Болъшакова, В. В. Кравченко, Л. Д. Исхакова, ИК спектроскопическое исследование квасцов, Ж. Неорг. Хим., XV, 2938-2944 (1970).

[48] J. A. Campbell, D. P. Ryan, L. M. Simpson, Interionic forces in crystals. II. Infrared spectra of $\mathrm{SO}_{4}$ groups and "octahedrally" coordinated water in some alums, Tutton salts, and the double salts obtained by dehydrating them, Spectrochim. Acta, 26A, 2351-2361 (1970).

[49] G. M. Venkatesh, P. S. Narayanan, Infrared absorption spectra of $\mathrm{K}, \mathrm{NH}_{4} \& \mathrm{Rb}$ aluminium alums, Ind. J. Pure Appl. Phys., 9, 39-43 (1971).

[50] A. Selvarajan, Raman \& infrared spectra thallium aluminium sulphate dodecahydrate and thallium aluminium selenate dodecahydrate, Ind. J. Pure Appl. Phys., 9, 166-168 (1971).

[51] С. Н. Андреев, М. Ф. Смирнова, К вопросу о состоянии молекул воды в гидратных оболочках ионов, Ж. Физ. Хим., XLVI, 1793-1796 (1972).

[52] N. Strupler, J. Guillermet, Étude de la déshydratation d'aluns de vanadium. II. Contribution à l'étude de la déshydratation, Bull. Soc. Chim. Fr., 1830-1834 (1974).

[53] R. S. Krishnan, P. S. Narayanan, G. M. Venkatesh, Spectroscopic study of sulphate group: order-disorder in alum family of crystals, Proc. $5^{\text {th }}$ Int. Conf. Raman Spectr., Freiburg, 624-625 (1976).

[54] H. H. Eysel, J. Eckert, Einkristall-Raman-spektren von alaunen. I. Innere schwingungen, frequenzbereich 300 bis $1200 \mathrm{~cm}^{-1}$, Z. anorg. Allg. Chem., 424, 68-80 (1976).

[55] J. Eckert, H. H. Eysel, G. L. Kampffmeyer, EinkristallRaman-spektren von alaunen. II. Raman-aktive gitterschwingungen und FIR-spektren, Z. anorg. Allg. Chem., 424, 81-86 (1976).

[56] H. H. Eysel, G. Schumacher, Dynamic sulfate disorder in potassium alum, a single crystal Raman study, Chem. Phys. Lett., 47, 168-170 (1977).

[57] S. P. Best, R. S. Armstrong, J. K. Beattie, Infrared metal-ligand vibrations of hexaaquametal(III) ions in alums, Inorg. Chem., 19, 1958-1961 (1980).

[58] A. K. Sood, A. K. Arora, S. Dattagupta, G. Venkataraman, Raman study of orientational dynamics of sulphate ions in potash alum, J. Phys. C: Solid State Phys., 14, 5215-5224 (1981).

[59] S. P. Best, R. S. Armstrong, J. K. Beattie, Vibrational spectroscopic studies of trivalent hexa-aqua-cations: single-crystal Raman spectra of caesium aluminium alums between 300 and $1200 \mathrm{~cm}^{-1}$, J. Chem. Soc. Dalton Trans., 1655-1664 (1982).

[60] P. Bernard, A. Ludi, Infrared and Raman spectra of the hexaaquaruthenium ions: normal-coordinate analysis for $\mathrm{Ru}\left(\mathrm{H}_{2} \mathrm{O}\right)_{6}{ }^{2+}$ and $\mathrm{Ru}\left(\mathrm{H}_{2} \mathrm{O}\right)_{6}{ }^{3+}$, Inorg. Chem., 23, 870-872 (1984).
[61] S. P. Best, J. K. Beattie, R. S. Armstrong, Vibrational spectroscopic studies of trivalent hexa-aqua-cations: single-crystal Raman spectra between 275 and $1200 \mathrm{~cm}^{-1}$ of caesium alums of titanium, vanadium, chromium, iron, gallium, and indium, J. Chem. Soc. Dalton Trans., 2611-2624 (1984).

[62] S. P. Best, J. K. Beattie, R. S. Armstrong, G. P. Braithwaite, Vibrational spectroscopic studies of tervalent hexa-aqua-cations: oriented single-crystal Raman spectra between 275 and $1200 \mathrm{~cm}^{-1}$ of the caesium rhodium alums $\mathrm{CsRh}\left(\mathrm{SO}_{4}\right)_{2} \cdot 12 \mathrm{H}_{2} \mathrm{O}, \mathrm{CsRh}\left(\mathrm{SeO}_{4}\right)_{2} \cdot 12 \mathrm{H}_{2} \mathrm{O}$, and $\mathrm{CsRh}\left(\mathrm{SO}_{4}\right)_{2} \cdot 12 \mathrm{D}_{2} \mathrm{O}$, J. Chem. Soc. Dalton Trans. 1771-1777 (1989).

[63] M. S. Brooker, H. S. Eysel, Raman study of the orientational dynamics in $\alpha$-potassium alum and in the deuterated and oxygen-18 enriched forms, J. Phys. Chem., 94, 540-544 (1990).

[64] V. I. Torgashev, Yu. I. Yuzyuk, L. F. Kirpichnikova, L. A. Shuvalov, Raman spectra of $\mathrm{CH}_{3} \mathrm{NH}_{3} \mathrm{Al}\left(\mathrm{SO}_{4}\right)_{2} \cdot 12 \mathrm{H}_{2} \mathrm{O}$ and $\left(\mathrm{CH}_{3}\right)_{2} \mathrm{NH}_{2} \mathrm{Al}\left(\mathrm{SO}_{4}\right)_{2} \cdot 6 \mathrm{H}_{2} \mathrm{O}$ crystals, Ferroelectrics, 110, 13-20 (1990).

[65] V. Petruševski, B. Šoptrajanov, Vibrational spectra of hexaaquacomplexes. I. Assignments of water librational bands in the spectra of some alums, J. Mol. Struct., 219, 67-72 (1990).

[66] R. Malekfar, W. F. Sherman, Optical and dielectric parameters of $\mathrm{KAl}\left(\mathrm{SO}_{4}\right)_{2} \cdot 12 \mathrm{H}_{2} \mathrm{O}$ derived from IR reflection measurements, J. Mol. Struct., 247, 343-354 (1991).

[67] S. P. Best, R. S. Armstrong, J. K. Beattie, Single-crystal Raman spectroscopy of the $\alpha$ alums $\operatorname{CsM}\left(\mathrm{SO}_{4}\right)_{2} \cdot 12 \mathrm{H}_{2} \mathrm{O}$ (M = Co or Ir) between 275 and $1200 \mathrm{~cm}^{-1}$, J. Chem. Soc. Dalton Trans., 299-304 (1992).

[68] B. Šoptrajanov, V. Petruševski, Vibrational spectra of hexaaquacomplexes. IV. Multiple bands in the $\mathrm{HOH}$ bending region of some alums, J. Mol. Struct., 293, 101104 (1993).

[69] R. S. Armstrong, J. K. Beattie, S. P. Best, B. D. Cole, P. L. W. Tregenna-Piggott, Low-temperature polarized single-crystal Raman spectra of the $\beta$ alums $\mathrm{CsM}\left(\mathrm{SO}_{4}\right)_{2} \cdot 12 \mathrm{H}_{2} \mathrm{O}(\mathrm{M}=\mathrm{Mo}$ or $\mathrm{Ru})$ between 275 and $1200 \mathrm{~cm}^{-1}$, J. Raman Spectr., 26, 921-927 (1995).

[70] G. Suresh, R. Ratheesh, R. S. Jayasree, V. U. Nayar, G. Keresztury, Infrared and polarized Raman spectra of $\mathrm{RbAl}\left(\mathrm{SO}_{4}\right)_{2} \cdot 12 \mathrm{H}_{2} \mathrm{O}$, J. Solid State Chem., 122, 333-337 (1996).

[71] P. L. W. Tregenna-Piggott, S. P. Best, Single-crystal Raman spectroscopy of the rubidium alums $\operatorname{RbM}^{\mathrm{III}}\left(\mathrm{SO}_{4}\right)_{2} \cdot 12 \mathrm{H}_{2} \mathrm{O}\left(\mathrm{M}^{\mathrm{III}}=\mathrm{Al}, \mathrm{Ga}, \mathrm{In}, \mathrm{Ti}, \mathrm{V}, \mathrm{Cr}, \mathrm{Fe}\right)$ between 275 and $1200 \mathrm{~cm}^{-1}$, Inorg. Chem., 35, 57305736 (1996).

[72] P. L. W. Tregenna-Piggott, S. P. Best, M. C. M. O'Brien, K. S. Knight, J. B. Forsyth, J. R. Pilbrow, Cooperative Jahn-Teller effect in titanium alums, J. Am. Chem. Soc., 119, 3324-3332 (1997).

[73] P. L. W. Tregenna-Piggott, M. C. M. O'Brien, H. U. Güdel, J. R. Pilbrow, S. P. Best, Paramagnetism of caesium titanium alum and the Jahn-Teller interaction, $J$. Chem. Phys., 107, 8275-8291 (1997).

[74] A. B. Berry, B. D. Cole, R. S. Armstrong, Raman spectra of the $\alpha$-alums $\mathrm{CsAl}\left(\mathrm{SeO}_{4}\right)_{2} \cdot 12 \mathrm{H}_{2} \mathrm{O}(\mathrm{M}=\mathrm{Ga}, \mathrm{In}), J$. Raman Spectrosc., 30, 73-76 (1999). 
[75] V. Ivanovski, V. M. Petruševski, B. Šoptrajanov, Vibrational spectra of hexaaquacomplexes. VIII. The antisymmetric $\mathrm{SO}_{4}$ stretching bands in alums: $\mathrm{LO}-\mathrm{TO}$ superior to correlation-field and site-group splitting, J. Mol. Struct., 480-481, 689-693 (1999).

[76] V. Ivanovski, V. M. Petruševski, B. Šoptrajanov, Vibrational spectra of hexaaquacomplexes. IX. Reflection infrared spectra, optical constants and longitudinal optical phonon-transversal optical phonon splitting in some alums, Vib. Spectrosc., 19, 425-429 (1999).

[77] V. Ivanovski, V. M. Petruševski, B. Šoptrajanov, M. Zugik, Vibrational spectra of hexaaquacomplexes. X. Raman and IR studies of the sulfate group disorder in $\alpha$ alums, J. Mol. Struct., 563-564, 329-333 (2001).

[78] V. M. Petruševski, B. Šoptrajanov, Vibrational spectra of hexaaquacomplexes. XI. Spectroscopic criteria for the classification of the alum types, Bull. Chem. Techn. Macedonia, 21, 103-110 (2002).

[79] P. Makreski, G. Jovanovski, S. Dimitrovska, Minerals from Macedonia. XIV. Identification of some sulfate minerals by vibrational (infrared and Raman) spectroscopy, Vib. Spectrosc., 39, 229-239 (2005).

[80] A. Eriksson, J. Lindgren, Model calculations of the vibrations of bonded water molecules, J. Mol. Struct., 48, 417-430 (1978).

[81] R. D. Shannon, Revised effective ionic radii and systematic studies of interatomic distances in halides and chalcogenides, Acta Crystallogr., A32, 751-767 (1976).

[82] S. Aleksovska, V. M. Petruševski, Lj. Pejov, Crystal structures of members in isostructural series: prediction of the crystal structure of $\mathrm{Cs}_{2} \mathrm{MnO}_{4}-\mathrm{A} \beta-\mathrm{K}_{2} \mathrm{SO}_{4}$ type isomorph, Croat. Chem. Acta, 70, 1009-1019 (1997).

[83] S. Aleksovska, S. C. Nyburg, Lj. Pejov, V. M. Petruševski, $\beta-\mathrm{K}_{2} \mathrm{SO}_{4}$ type isomorphs: prediction of structures and refinement of $\mathrm{Rb}_{2} \mathrm{CrO}_{4}$, Acta Crystallogr., B54, 115-120 (1998).

[84] S. Aleksovska, V. M. Petruševski, B. Šoptrajanov, Calculation of the structural parameters in isostructural series: the kieserite group, Acta Crystallogr., B54, 564567 (1998).

[85] V. M. Petruševski, S. Aleksovska, Dependence of the crystal structure parameters on the size of the structural units in some isomorphous/isostructural series, Croat. Chem. Acta, 72, 71-76 (1999).

[86] V. Petruševski, S. Aleksovska, Correlations between effective crystal radii and unit cell volume in Tutton salts, Croat. Chem. Acta, 64, 577-583 (1991).

[87] V. Petruševski, S. Aleksovska, Structural correlations in alums, Croat. Chem. Acta, 67, 221-230 (1994).

[88] V. M. Petruševski, DISTAN - a computer program for calculation of interatomic distances and angles in crystal structures, unpublished.

[89] H. M. Nussenzveig, Causality and Dispersion Relations, Academic Press, New York, 1972.

[90] GRAMS ANALYST ${ }^{\mathrm{TM}}$ for PE-2000 FT-IR, Version 3.01B Level II, Galactic Indus-tries, 1994.

[91] GRAMS/32 Spectral Notebase, Version 4.10, Galactic Industries Corporation, 1996. 
